\title{
Promise cut short: the career of William Anderson
}

\author{
AW Beasley \\ Retired Orthopaedic Surgeon, Wellington, New Zealand
}

\begin{abstract}
This paper traces the career of William Anderson, naval surgeon and naturalist, who served in Cook's ship Resolution on the second and final voyages, and died of tuberculosis high in the Arctic.
\end{abstract}

KEYWORDS William Anderson, naval medicine, James Cook, Pacific exploration, natural history
Correspondence to AW Beasley 37 Hay Street, Oriental Bay, Wellington $60 \mathrm{I}$, New Zealand

\section{tel. $+64438454 / 4$}

e-mail alwynbeasley@hotmail.com

\section{DECLARATION OF INTERESTS No conflict of interests declared.}

When William Anderson, surgeon of HM sloop Resolution, died on 3 August 1778, high in the Bering Sea, Britain lost a natural scientist of some distinction and even greater promise. Captain James Cook wrote of his subordinate and friend:

Mr Anderson my Surgeon who had been lingering under a consumption for more than twelve Months, expired between 3 and 4 this after noon. He was a Sensible Young Man, an agreeable companion, well skilld in his profession, and had acquired much knowlidge in other Sciences, that had it pleas'd God to have spar'd his life might have been useful in the Course of the Voyage.'

Cook's estimate, though stilted for a eulogy, is worth studying as the basis of our own appreciation of this young man.

\section{A SENSIBLE YOUNG MAN}

Anderson was a Scot, the second son of Robert Anderson, a respected North Berwick schoolmaster, and was born on 28 December 1750. Between 1766 and 1769 he attended classes at Edinburgh University, where he sat at the feet of Alexander Monro secundus (Figure I), the middle and arguably most distinguished member of the three generations of namesakes who held the chair of anatomy through much of the eighteenth and nineteenth centuries. His father Alexander primus dominated anatomy teaching in his generation, but secundus is considered by many to have excelled him. (Tertius could not maintain the family standard and his son David, after graduating in medicine from Edinburgh, migrated to New Zealand where he and his successors regained something of the reputation that tertius had lost.)

There is tantalising evidence in the National Museum of Scotland of the friendship that developed between Anderson and his mentor: the museum houses a collection of bird paintings (Figure 2) and at the end of the series a map of the Resolution's track from Cook's second voyage is annotated in

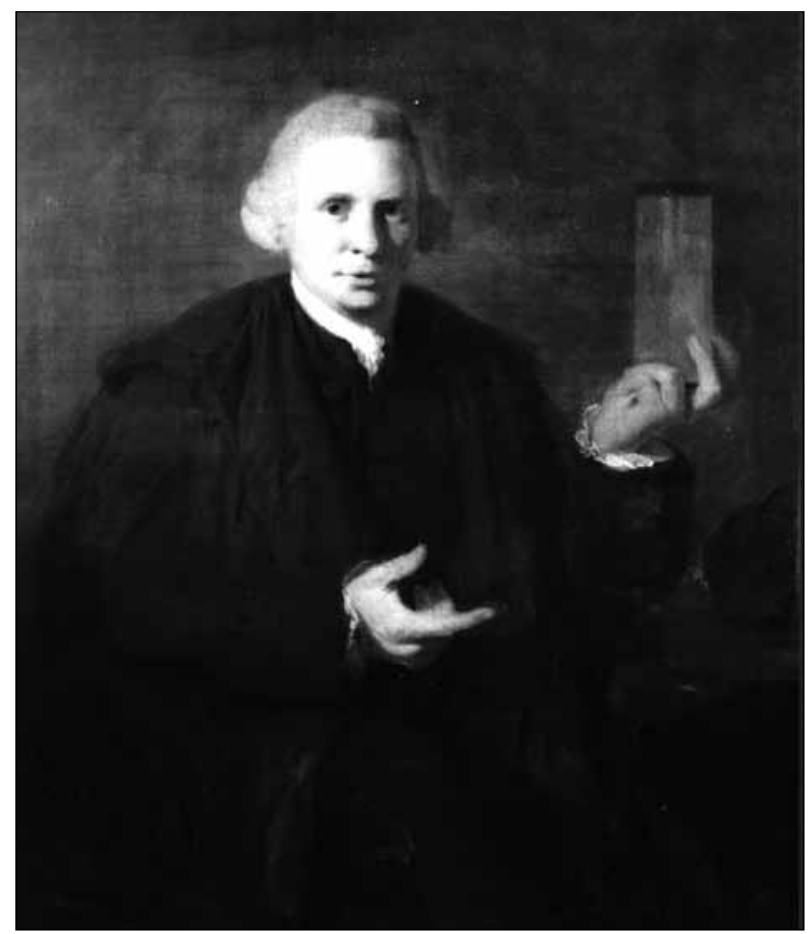

FIGURE I Alexander Monro secundus by John Seton. William Anderson became friendly with his master, Monro secundus, after attending his classes at Edinburgh University. (RCSEd Collection)

Anderson's handwriting. The collection is known to have been presented by Alexander Monro secundus; what has proved impossible to confirm is the identity of the bird painter. Anderson may possibly have done these, as well as annotating the map, but there is nothing in the series, or in Anderson's own journals, to confirm this attribution.

Anderson did not graduate from Edinburgh, but qualified at Surgeons' Hall in London where he passed the examinations in 1768 and 1770 . One has to wonder if his Scots ancestry prompted the same examiners' gibes as endured by Roderick Random. ${ }^{2}$ That character's ordeal, as chronicled by another Scot, Tobias Smollett, saw him present himself 'with a quaking heart' at Surgeons' Hall. 


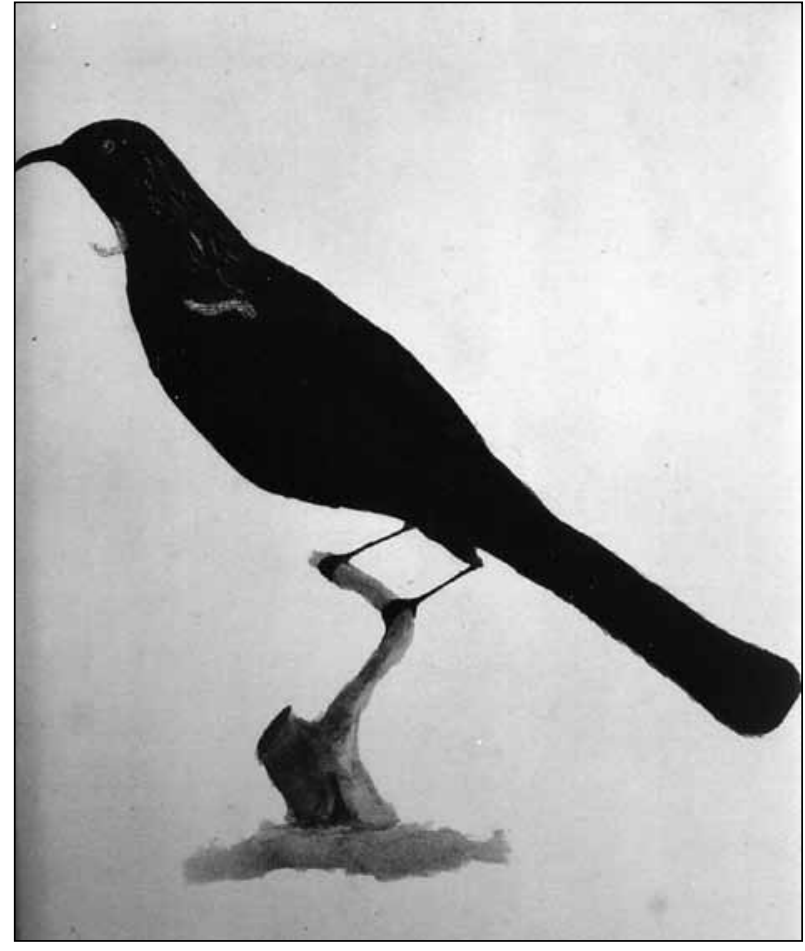

FIGURE 2 The collection of bird paintings given by Monro to the Royal Scottish Museum is believed to have originated with Anderson. This is the New Zealand tui or parson bird; the identity of the artist is unknown. (Author's collection)

I was conducted into a large hall, where I saw about a dozen of grim faces, sitting at a long table, one of whom bade me come forward... The first question he put to me was, "where was you born?" To which I answered,"in Scotland."... and when I informed him that I had served three years only, he fell into a violent passion, swore it was a shame and a scandal to send such raw boys into the world as surgeons; that it was a great presumption in me, and an affront upon the English, to pretend to sufficient skill in my business, having served so short a time, when every apprentice in England was bound seven years at least... This exordium... reduced me to such a situation that I was scarce able to stand; which being perceived by a plump gentleman who sat opposite to me, with a skull before him, he said, Mr Snarler was too severe upon the young man; and... examined me touching the operation of the trepan, and was very well satisfied with my answers. ${ }^{2}$

Random was rescued by a debate between two of his examiners on the possibility of survival after a wound of the intestines, and...

In less than a quarter of an hour I was called in again, received my qualification sealed up, and was ordered to pay five shillings. ${ }^{2}$

Thus qualified, he was posted to HMS Thunder.
Anderson for his part served briefly on the HMS Barfleur, but was posted to Resolution as surgeon's mate on 3 December 177I, joining the ship on 12 December.

\section{COOK'S SECOND VOYAGE}

The Resolution had begun her career as a Whitby collier, and had been bought into the Navy in the light of Cook's experience on the Endeavour voyage, which had taught him two things: that these craft, flat-bottomed and capacious, were ideal for exploration into unknown places and that a two-ship expedition could expect to cope better with sudden misfortune, such as Endeavour had experienced on the Great Barrier Reef in 1770, with nearfatal results.

Accordingly, the Navy bought in two fairly new colliers which, after several rapid changes of name became Resolution and Adventure. Cook's findings on the original voyage had gone far towards demolishing the fiction of 'the Great Southern continent', but there was still enough of the South Pacific unexplored to have suggested to him how a repeat voyage might be structured so as to put the issue beyond all doubt. Joseph Banks, who had travelled as 'scientific adviser' in Endeavour, and achieved celebrity on his return, took it upon himself to function as 'chief executive' for the next voyage. He began by demanding the building of an extra deck on Resolution to accommodate his suite of fourteen persons, including two horn players to entertain him in the evenings (and, as later emerged, a young woman who was to join the ship at Madeira as Banks's secretary, doubtless to provide more intimate entertainment). Banks was influential enough to have his structural wishes gratified but this extra tophamper made Resolution so unstable that it had to be removed before she could be deemed seaworthy. Banks thereupon withdrew from all involvement with the expedition.

In his place the Forsters were engaged: Johann Reinhold and his son George. The father was an erudite sociopath and young George able, but under his father's thumb. They would be part of the burden that Anderson had to bear as he matured into the expedition's most valuable, though informal, ethnographer and natural scientist. He was helped by the fact that James Patten, Resolution's surgeon and the son of an Irish parson, was diplomatic enough to establish a measure of friendship with the Forsters, thus shielding Anderson from most of their spite.

\section{'MUCH KNOWLIDGE IN OTHER SCIENCES'}

Most of their spite, but not all. At Balabio, off the northern tip of New Caledonia, Anderson made a collection of shells during a shore excursion. It was of a standard to excite the Forsters' envy. When they published an unauthorised account of the voyage, issued in George's name to get round the problem of authorisation 


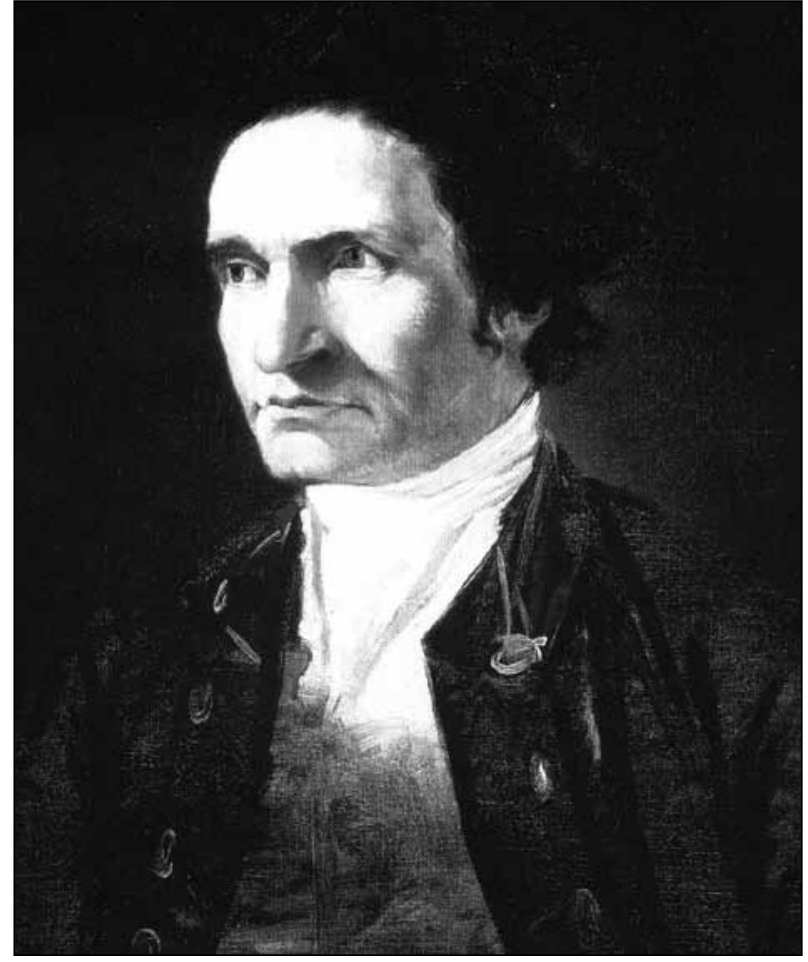

FIGURE 3 James Cook by William Hodges. When Hodges, the artist on Cook's second voyage, painted the explorer afterwards, it is evident that he was depicting a tired man. (Courtesy of the National Maritime Museum Greenwich)

but essentially the father's opinions, they referred bitterly to the collector and his collection:

One of the surgeon's mates, who went on this excursion, collected a prodigious variety of new and curious shells upon the island of Ballabeea, and likewise met with many new species of plants, of which we did not see a single specimen in the districts we had visited; but the meanest and most unreasonable envy taught him to conceal these discoveries from us, though he was utterly incapable of making use of them for the benefit of science. ${ }^{3}$

Thus, although Lysaght has written that Anderson 'probably benefited considerably from working with the Forsters' 4 the benefits could have been so much greater had these official naturalists been less paranoid.

Anderson's ear for the indigenous languages of the islands visited on this voyage was such that he was able to compile vocabularies for Easter Island, the Marquesas, the Friendly Islands (Tonga), Mallicolo (Malekula), Tanna, New Caledonia, New Zealand andTahiti. ${ }^{5}$ The Tahitian vocabulary (28 pages) was later published as an appendix to Canon Douglas's edition of Cook's account of the voyage.

Anderson's own journal for this voyage has not survived, although he is known to have kept one, because he later referred to items in it. His natural history collection from the voyage came to the notice of Daniel Solander (Banks's fellow-scientist from the first voyage) who went aboard Resolution when she anchored in the Thames on her return, on 13 August 1775; but he did not see Anderson himself. This is to be regretted because, had the two men met then, Solander might well have enticed Anderson on to the staff of the British Museum where he himself occupied a position of some influence.

Banks had withdrawn from the second voyage in a huff. To console himself he went to Iceland, and Solander, always loyal, accompanied him. Out of this experience he compiled a Flora Islandica. On his return Solander was appointed Keeper of the Natural History Department of the British Museum and in 1774 he was elected to the council of the Royal Society. As loyal to Cook as he had been to Banks, he hastened to meet Resolution and report on Cook's health and wellbeing to Banks. ${ }^{6} \mathrm{Had}$ he seen Anderson, he might well have sought to recruit him, and so saved his life. As it was, Cook chose Anderson as surgeon for the third voyage.

\section{COOK'S THIRD VOYAGE}

The second voyage was flawless in conception, and highly successful in its execution. By contrast, the third set out to test a hypothesis (the presumed existence of a navigable channel between the Pacific and Atlantic Oceans, around the top of the North American continent), and the hypothesis was founded on a mixture of riddle, myth and fallacy. The riddle was this: do two converging bodies of water signify continuity between them? It was a question that had been asked since America was first discovered by Europeans and then monopolised by the Iberian nations to create a barrier between the rest of Europe and the fabled riches of the East. The myth was the 'strait of Anian' which was supposed to extend across the width of North America: Sir Francis Drake was told to make use of it; a Spanish admiral named Bartholomew de Fonte was reported to have used it - and even proof that no such person had ever existed did not serve to dispel the myth.The fallacy was that seawater does not freeze, and so sea ice must be the product of rivers, must therefore be seasonal, and thus by implication passable.

In the course of being treated as a celebrity after the second voyage - audiences with the King, Fellowship of the Royal Society and the award of its Copley medal Cook was persuaded that he was just the person to test the hypothesis. The adulation left him little time to oversee what became a shoddy refit of Resolution and, when this third expedition was put together, Cook, already a tired man (Figure 3) after almost a decade of continuous sea voyaging in unexplored waters, was provided with a ship that bore little resemblance to the trim craft of four years earlier. 
William Anderson had meanwhile managed a brief posting to the frigate Milford at the end of 1775, and had become infected with tuberculosis. The well-regarded surgeon who joined Resolution on I5 February 1776 was already a doomed man.

So was Charles Clerke, who took command of Resolution's consort. Adventure being unavailable for this voyage, the Navy had bought in yet another Whitby collier, naming her Discovery; at just under 300 tons, she was the smallest of all the ships associated with Cook's voyages. Clerke had been rash enough to stand guarantor for the debts of his brother Sir John Clerke and had spent a period in the King's Bench prison as a result. This time had sown the seeds of his own demise for he too brought tuberculosis with him to the expedition.

\section{'WELL SKILLD IN HIS PROFESSION'}

Resolution was first away and waited for Discovery at Cape Town. That part of the voyage had been enough to demonstrate the poor condition of Resolution, for within three days of sailing she had developed leaks forward into the sail room and store rooms and aft into the officers' cabins. Anderson's cabin was one of the worst affected, although he made no mention of it at that time, being preoccupied with a number of scientific observations: he recorded latitude by dead reckoning and observation, longitude by lunars and the watch, magnetic variation, temperature readings throughout the day, the barometer reading and the effect of the ship's movement upon it, and a comparison of sea and air temperature. His curiosity was wide-ranging, so that he speculated on wind patterns and their effect on the ship's performance; but on 16 September, two months after departure, he too had to take note of Resolution's poor state.

The ship made a great deal of water at the side seams which wet her entirely between decks so that few could sleep dry in their beds. This was not from the rain so much as the sea breaking upon her side. In short it appears that the negligence of those who caulk'd her has been the cause of this: a circumstance so uncomfortable in a long voyage \& so unfavourable to the health of the people that it well deserves the enquiry of those under whose inspection ships are fitted out. ${ }^{7}$

Here in one extract is the shrewd observer, the careful recorder and the caring surgeon, concerned for the wellbeing of the people for whom he bore responsibility. When Discovery caught up at Cape Town, it was Anderson who recorded that 'they had the misfortune to lose one of their men on the passage who fell overboard but were in other respects well and healthy'.

The ships' next call was atVan Diemen's Land (Tasmania) where Anderson found the Aborigines 'mild and chearfull without reserve or jealousy of strangers'. 'The New Zealand Maori, by contrast, he considered 'to be of a suspicious or mistrustful temper'10 and 'in trading exult if they think they have trick'd you in the bargain'." Yet he was full of admiration for their skills:

Their master piece seems to be carving, which is found in the most triffling things, and in particular the heads of their canoes are sometimes done in such a manner that not only shows much design but is also an example of their great labour and patience in execution. ${ }^{8}$

Approaching 'Savage island discovered by Captn Cook in 1774' (Niue) he reflected on the effect of the weather on the health of his charges:

The heat which has been great for this month past becomes more disagreeable in the close rainy weather... It is however remarkable enough that though the only refreshment we have had since leaving the Cape of good hope was that at new Zeeland there is not yet a single person sick from the constant use of salt food or vicissitude of climate. ${ }^{12}$

At Tonga, while Cook speculated on the interrelationships of the royal families and the culture and customs of the people, Anderson provided a counterpoint by describing the geography of the country and the health of its people. He identified club foot, which is a condition prevalent throughout Polynesia:

There are... very few natural defects or deformitys to be found amongst them [but] they are... not absolutely free from such defects, as we saw two or three with their feet bent inwards..$^{13}$

(As a more recent comparison, when I conducted a survey of crippling conditions in neighbouring Samoa in 1967, talipes [20 cases] was second only to poliomyelitis [30] as a cause of disability in the 150 cases seen.) Anderson also commented on the prevalence of elephantiasis:

There are two other diseases which make themselves to be noticed from their frequency, one of which is an indolent firm swelling or tumour which affects the legs \& arms \& increases them to an extraordinary size in their whole length: and the other a tumour of the same sort in the testicles which sometimes exceed the size of the two fists. ${ }^{14}$

Exactly 100 years later the filarial parasite would be discovered by Sir Patrick Manson.

And - at the border between surgery and society Anderson remarked on the 'odd custom' by which 'when they suspect themselves in danger from sickness they cut off their little finger as a propitiation to the deity'. Describing this, he mentioned that many were "cut so 
short that they have incroach'd on the bone of the hand which joins to it'. ${ }^{15}$ That is to say, the Tongans would appear to have anticipated twentieth century hand surgery in excising the head of the fifth metacarpal when amputating the little finger, except in heavy manual workers. Performed with an oblique section, the procedure preserves a nearnormal contour along the ulnar border of the hand.

\section{'AN AGREEABLE COMPANION'}

The expedition sailed on to Tahiti and its neighbouring islands. By this time both Clerke and Anderson were becoming frail, and Clerke hardly able to get ashore. Many years later James Burney recorded that:

Anderson represented to Captain Clerke their inability to encounter the severities of a frozen climate, and they mutually agreed to ask leave of Captain Cook to resign their situations, that they might remain where they were, and trust themselves to the care of the natives, as the only hope left them of being restored to health. ${ }^{16}$

Burney is an interesting man in his own right. The son of Dr Charles Burney, the historian of music, and brother of Fanny Burney (Mme d'Arblay) the diarist, he was second lieutenant of Adventure on the second voyage and sailed as first lieutenant of Discovery on the third. He commanded her for the last part of the homeward voyage. In retirement, an admiral by right of survival, he became a respected historian of Pacific voyaging. Burney went on in his later account to describe the lines of argument by which the two delayed approaching Cook until it was too late to do so: their sense of loyalty had exceeded their instinct for self-preservation.

By 21 December 1777 the ships had reached the islands of the Hawaiian chain and, while watering parties were at work, Cook went ashore at Kauai 'and took a walk up the Vally, accompanied by Dr Anderson and Mr Webber [the artist]; conducted by one of the Natives and attended by a tolerable train. ${ }^{17}$ It was one of Anderson's last recorded shore visits. It was also the start of the adulation Cook would experience in Hawaii, where the locals saw him as the reincarnation of the god Lono, until the fateful day in February 1779 when adulation turned to murder. Anderson's next recorded shore visit came on 4 May 1778. His surgeon's mate and good friend, the Welshman David Samwell, noted in his journal:

To Day Captn Cook accompanied by the Surgeon went ashore on an Island off which Bering came to anchor,... Captn Cook went up the Hill above the Beach. ${ }^{18}$

Plainly Anderson could no longer climb a hill. Until that time his strength had held up somewhat better than Clerke's, but Clerke was to outlive him by a year (and indeed to outlive Cook by six months). Anderson died on 3 August, 1778 (Figure 4). Clerke's tribute to Anderson is a touching one:

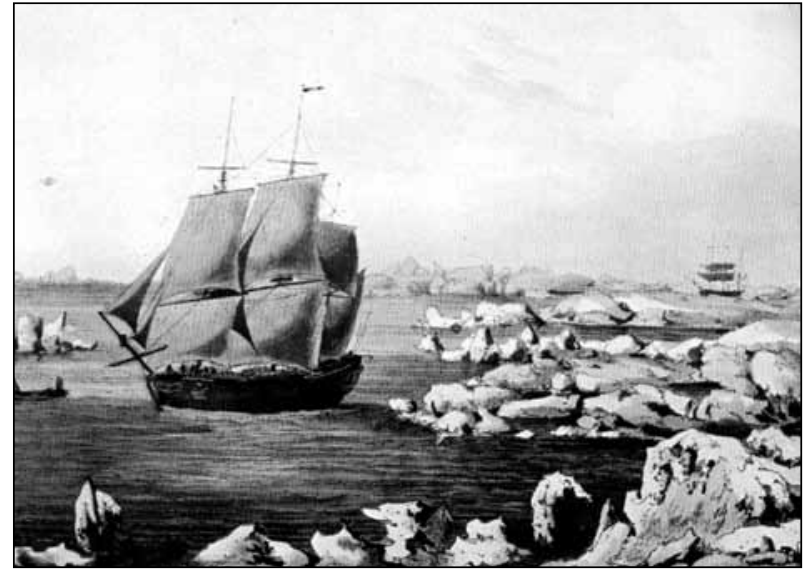

FIGURE 4 Anderson died high in the Arctic; John Webber, artist on the final voyage, painted the conditions they faced: 'The Resolution beating through the ice, with the Discovery in the most eminent [sic] danger'. Drawing [detail] by John Webber. (Sourced from Alexander Turnbull Library, Wellington NZ)

The Death of this Gentleman, is a most unfortunate stroke to our Expedition alltogether; his distinguished Abilities as a Surgeon, \& unbounded humanity, render'd him a most respectable and much esteemed Member of our little Society; and the loss of his superior Knowledge of, and wonted attention to the Science of Natural History, will leave a Void in the Voyage much to be regretted. ${ }^{16}$

Anderson was buried at sea, off an island which Cook named for him at the time, Bering's St Lawrence Island, discovered by him in 1728. It has since reverted to its original name. Even in death, poor Anderson received a raw deal. Had he survived the voyage, it is a fair assumption that he would have become more than the 'esteemed member of our little Society' of Clerke's tribute: for almost certainly he would have been made a Fellow of the Royal Society, quite promptly, on the basis of his contribution to the understanding of the Pacific, its languages and its natural history.

He was one of a series of able surgeon-naturalists who travelled with Cook but who, because Cook casts so long a shadow, have tended to be obscured by their chief. His abilities deserve better recognition.

\section{REFERENCES}

I Beaglehole JC, editor. The voyage of the Resolution and Discovery, I 776-I 780 (2 vols), volume III of the Journals of Captain James Cook on his voyages of discovery (4 vols). Cambridge: Cambridge University Press (for the Haylukt Society); 1967. p. 406.

2 Smollett T. The adventures of Roderick Random [1748]. London: Dent; 1964. p. 83ff.

3 Beaglehole JC, editor. The voyage of the Resolution and Adventure, I772-1775, volume II of the Journals of Captain James Cook on his voyages of discovery (4 vols). Cambridge: Cambridge University Press (for the Haylukt Society); 196I. p. xlvi n. 
4 Lysaght A. Some eighteenth century bird paintings in the library of Sir Joseph Banks (1743-1820). Bull Brit Mus Nat Hist (Historical Series) I:25I-37I.

5 Beaglehole JC, editor. The voyage of the Resolution and Adventure, 1772-1775, volume II of the Journals of Captain James Cook on his voyages of discovery (4 vols). Cambridge: Cambridge University Press (for the Haylukt Society); 1961. p. cxxvi.

6 Solander to Banks, I4 August 1775. Mitchell Library, Sydney. Banks papers $\mathrm{M} \mathrm{I-4}$

7 Beaglehole JC, editor. The voyage of the Resolution and Discovery, 1776-I 780 (2 vols), volume III of the Journals of Captain James Cook on his voyages of discovery (4 vols). Cambridge: Cambridge University Press (for the Haylukt Society); 1967. p. 749. [Anderson's journal]

8 Beaglehole JC, editor. The voyage of the Resolution and Discovery, I776-I 780 (2 vols), volume III of the Journals of Captain James Cook on his voyages of discovery (4 vols). Cambridge: Cambridge University Press (for the Haylukt Society); 1967. p. 756.

9 Beaglehole JC, editor. The voyage of the Resolution and Discovery, 1776-I 780 (2 vols), volume III of the Journals of Captain James Cook on his voyages of discovery (4 vols). Cambridge: Cambridge University Press (for the Haylukt Society); 1967. p. 786.

10 Beaglehole JC, editor. The voyage of the Resolution and Discovery, 1776-I 780 (2 vols), volume III of the Journals of Captain James Cook on his voyages of discovery (4 vols). Cambridge: Cambridge University Press (for the Haylukt Society); 1967.p. 8I3.

8 Beaglehole JC, editor. The voyage of the Resolution and Discovery, 1776-I 780 (2 vols), volume III of the Journals of Captain James Cook on his voyages of discovery (4 vols). Cambridge: Cambridge University Press (for the Haylukt Society); 1967. p. 8I3. [Anderson's journal]

9 Beaglehole JC, editor. The voyage of the Resolution and Discovery, 1776-I 780 (2 vols), volume III of the Journals of Captain James Cook on his voyages of discovery (4 vols). Cambridge: Cambridge University Press (for the Haylukt Society); 1967. p. 858-9. [Anderson's journal]
10 Beaglehole JC, editor. The voyage of the Resolution and Discovery, I776-I 780 (2 vols), volume III of the Journals of Captain James Cook on his voyages of discovery (4 vols). Cambridge: Cambridge University Press (for the Haylukt Society); 1967. p. 926. [Anderson's journal]

II Beaglehole JC, editor. The voyage of the Resolution and Discovery, I776-I 780 (2 vols), volume III of the Journals of Captain James Cook on his voyages of discovery (4 vols). Cambridge: Cambridge University Press (for the Haylukt Society); 1967. p. 927-8. [Anderson's journal]

12 Beaglehole JC, editor. The voyage of the Resolution and Discovery, I776-I 780 (2 vols), volume III of the Journals of Captain James Cook on his voyages of discovery (4 vols). Cambridge: Cambridge University Press (for the Haylukt Society); 1967. p. 947. [Anderson's journal]

13 Burney J. Chronological history of North-eastern voyages of Discovery. In: Beaglehole JC. The life of Captain James Cook. London:A \& C Black; 1974. p. 568-9.

14 Beaglehole JC, editor. The voyage of the Resolution and Discovery, I 776-I 780 (2 vols), volume III of the Journals of Captain James Cook on his voyages of discovery (4 vols). Cambridge: Cambridge University Press (for the Haylukt Society); 1967. p. 269. [Cook's journal]

15 Beaglehole JC, editor. The voyage of the Resolution and Discovery, I776-I 780 (2 vols), volume III of the Journals of Captain James Cook on his voyages of discovery (4 vols). Cambridge: Cambridge University Press (for the Haylukt Society); 1967. p. I 105-6. [Samwell's journal]

16 Beaglehole JC, editor. The voyage of the Resolution and Discovery, I776-1780 (2 vols), volume III of the Journals of Captain James Cook on his voyages of discovery (4 vols). Cambridge: Cambridge University Press (for the Haylukt Society); I 967. p. 406, n. I. [Clerke's journal] 